\title{
Mutual Interaction Analysis Between Stock Market Index and Financial Indicators By Granger Causality Method
}

\section{Özge DEMIRKALE ${ }^{1}$}

\begin{abstract}
This study aims to measure the mutual relationship between exchange rates and interest rate and the BIST100 index. For this purpose, the relationship between the variables used in the study was analyzed using the VAR model method. The relationship between the stock market index, dollar/ TL, Euro/TL, and the interest rate was evaluated at the level of 5\% and $10 \%$ significance with the VAR method. The reaction of the stock market index against a one-unit shock to be applied to exchange rates and interest rate were examined by the effect-reaction analysis. January 2005-March 2019 period based on monthly data, Dollar/TL, Euro/TL, interest rate, and BIST100 index variables were used in the study. According to the results obtained from the analysis, it was determined that the Dollar/TL variable is the cause of the stock market index variable. The study also found that the Dollar/TL variable is the cause of the Euro/TL and interest rate variables.
\end{abstract}

Keywords: Stock Market Index, Exchange Rates, Interest Rate, VAR Method.

\footnotetext{
${ }^{1}$ Dr. Öğr. Üyesi. İktisadi ve İdari Bilimler Fakültesi İşletme bölümü, İstanbul Aydın Üniversitesi, ozgedemirkale@ aydin.edu.tr, ORCID: 0000-0002-4227-3934

Doi Num: 10.17932/IAU.FCPE.2015.010/fcpe_v06i1001
} 


\section{Borsan Endeksi İle Finansal Göstergeler Arasındaki Karşılıklı İlişkinin Granger Nedensellik Yöntemi İle Analizi}

\section{ÖZ}

Bu çalışma, döviz kurları ve faiz oranı ile BIST100 endeksi arasındaki karşılıklı ilişkiyi ölçmeyi amaçlamaktadır. Bu amaçla çalışmada kullanılan değişkenler arasındaki ilişki VAR modeli yöntemi ile analiz edilmiştir. VAR yöntemi ile borsa endeksi, Dolar/TL, Euro/TL ve faiz oranı arasındaki ilişki $\% 5$ ve $\% 10$ anlamlılık düzeyinde değerlendirilmiştir. Etki-tepki analizi ile döviz kurları ve faiz oranına uygulanacak bir birimlik şok karşısında borsa endeksinin tepkisi incelenmiştir. Ocak 2005-Mart 2019 dönemi aylık verilerinin esas alındığı çalışmada Dolar/TL, Euro/ TL, faiz oranı ve BIST100 endeksi değişkenleri kullanılmıştır. Analizden elde edilen sonuçlara göre Dolar/TL'nin borsa endeksi değişkenin nedeni olduğu tespit edilmiştir. Çalışmada ayrıca; Dolar/TL değişkeninin Euro/ TL ve faiz değişkenlerinin nedeni olduğu saptanmıştır.

Anahtar Kelimeler: Borsa Endeksi, Döviz Kurları, Faiz Oranı, VAR Yöntemi

\section{INTRODUCTION}

Due to the effects of financial liberalization policies, the reduction of governments' control over capital movements has led to the deepening of the financial system. The liberalisation of capital movements has led to the development of the mutual relationship between stock markets and exchange rates. The risk of stock markets being higher than other investment instruments may cause investors to evaluate their savings in different investment instruments such as exchange, interest, and gold.

Exchange rates are one of the important macroeconomic indicators in the economy. Exchange rates, especially in developing countries, are affected by many factors including economic, political and social factors. An increase in exchange rates may cause the investor to keep his savings in foreign currency. In this context, exchange-denominated financial assets are becoming more attractive (Central Bank, Monetary Policy Report, 2002,8). 
In the literature, the relationship between exchange rates and stock prices have been studied by many researchers. Studies show that there is a directional relationship between exchange rates and stock market. However, when the causality relationship between the two variables is analyzed, it is observed that there is not exactly a consensus. GrangerHuang et al. (2000), Şentürk and Dücan (2014), Delgado et al. (2018) concluded that exchange rates affect on the stock market. In contrast, Tabak (2006), Ghazali-Ismail et al. (2008) et al. concluded that the stock market affects on exchange rates. There are studies in which there is no causality Nieh and Lee (2001) relationship between the two variables.

In the literature, it is observed that there is no consensus in studies examining the relationship between interest rate and stock market index. Some studies have shown a positive relationship between the two variables, while some studies have identified a negative relationship. Stock markets are an investment vehicle. The performance of the markets as an investment instrument may be negatively affected if the investor wishes to evaluate his savings in assets with high interest rate returns.

This study covers the relationship between BIST100 index and financial indicators in Turkey. January 2005-March 2019 based on the monthly data, the study aims to measure the mutual sensitivity and degree of interaction between Dollar/TL, Euro/TL, and interest rate with BIST100 index. In this context, first studies in the literature examining the relationship between capital markets and exchange rates and interest rate were examined. The results obtained from the analysis were given after the section where the method and data set were determined.

\section{LITERATURE}

In literature, the relationship between the stock market index and financial and macroeconomic indicators have been studied by many researchers. When the relationship between the capital market index and exchange rates is examined, it is seen that no consensus can be reached. Likewise, in some studies, a causal relationship was determined between interest rate and shares, while in some studies no causal relationship was determined. Some of the works in literature are summarized as follows. 
Aggarwall (1981) examined the relationship between the U.S. Dollar and stock prices between 1974 and 1978. According to the results of the study, there was a positive correlation between stocks and the U.S. Dollar. SoenenHennigar (1988), in their analysis for the years 1980-1986, concluded that there was a negative relationship between the stock market index and the exchange rates in the United States.

Granger-Huang et al. (2000) analyzed the causal relationship between stock market indices and exchange rates of Asian countries between 1986-1998. According to the results from the study, In South Korea, the exchange rate was found to be the cause of the stock market index. In the Philippines, a one-way causality relationship was determined from the stock market index to the exchange rate.

Nieh and Lee (2001) studied the relationship between shares and exchange rates of the G7 countries between the years 1993 and 1996, and found that, there was no significant relationship between these variables in the long run.

Tabak (2006) examined the relationship between the shares and exchange rates in Brazil between the years 1994 and 2002 with the Granger causality analysis method. According to the findings obtained in the analysis, it was determined that the stock market index was the cause of the exchange rates.

Ghazali-Ismail et al. (2008) examined the relationship between exchange rates on the capital market index, i.e. in Malaysia between the years 2005 and 2007, and they conclude the existence of one-way causality relationship from the stock market index to the exchange rates.

Akbaş (2013) examined the relationship between stock market index and interest rate for Turkey. According to the results obtained from the analysis, it was determined that there was a long-term relationship between the stock market index and the interest rate.

Şentürk and Dücan (2014) examined the relationship between stock market index, exchange rate and interest rate in Turkey between the years 1997 and 2013 using VAR method. The result was that the exchange rate was found to be the cause of the stock market index. In addition, there is a relationship from interest rate to exchange rate. 
Topaloğlu and Karakozak (2018) investigated the relationship between BIST bank return and macroeconomic and financial indicators using panel data analysis. According to the results obtained from the analysis, there was a significant and negative relationship between exchange rate, interest rate and money supply.

Delgado et al. (2018) examined the relationship between the stock market and exchange rates, oil prices in Mexico using the VAR method, taking into account monthly data from 1992-2017. The result was that the exchange rate had a negative impact on the stock market.

\section{DATA SET AND METHOD}

January 2005 - March 2019 monthly data were analyzed in the study. The variables included in the study are the BIST100 index, Dollar/TL, Euro/ TL and monthly interest rate of 1-year bond interest. The data set used in the study includes the Capital Markets Board, the Central Bank of the Republic of Turkey, investing.com compiled from their website.

The most commonly used method to check whether the data-set is stationary or not is the Augmented Dickey-Fuller (ADF) unit root test developed by Dickey and Fuller. Static analysis of the variables included in the study was investigated with the help of ADF unit root test. The following regression equation is used in this analysis. The ADF test consists of adding constant term, trend-constant term to the following regression equation (Gujarati and Porter, 2014: 757).

Lag length in ADF testing is determined using Akaike (AIC), Schwarz (SC) and Hannan-Quinn (Hannan-Quinn information criterion) information criteria. In this study, it was preferred to use the Schwarz information criterion. The probability value of the statistical result should be less than 0.05 according to the ADF test applied to the variables.

VAR model was developed by C. Sims in 1980 (Sims, 1980, s. 1-49). The VAR model is an econometric model for explaining the mutual relations between variables. Sims stated that each variable can affect another without requiring the internal and external separation of the variables contained in the econometric model. 
A simple VAR model consisting of two variables such as $\mathrm{X}$ and $\mathrm{Z}$ can be shown as (Çakmak et al. 2002, 35-36).

$$
\begin{aligned}
& x_{t}=\alpha_{10}+\sum_{i=1}^{p} \alpha_{11 . i} X_{t-1}+\sum_{i=1}^{p} \alpha_{12 . i} Z_{t-1}+\varepsilon_{i t} \\
& z_{t}=\alpha_{20}+\sum_{i=1}^{p} \alpha_{21 . i} X_{t-1}+\sum_{i=1}^{p} \alpha_{22 . i} Z_{t-1}+\varepsilon_{t}
\end{aligned}
$$

The VAR model provides an opportunity to examine and determine the interaction between two variables. In addition, the effects of one standard deviation shock on other variables and/or variables in one of the variables can be examined with effect-response functions. The equation expressed above for the VAR model can also be estimated for more than two variables.

In order for VAR analysis to be valid, some assumptions must be provided. The appropriate lag length should be determined in the model, and it should also be determined that the appropriate lag length is not an autocorrelation and changing variance problem in the model. With the AR roots table, it can be tested whether the model shows a stable structure. If all modules are located within the unit circle, then the calculated VAR model can be said to have a stationary (Hendry ve Juselius, 2000, s. 10). Lagrange Çarpanı (Lagrange Multiplier - LM) test developed by Breusch and Godfrey was used in the model created for Granger causality analysis to test whether an autocorrelation problem exists. The Granger causality test developed by Granger was applied to determine the direction of the relationship between variables (Granger, 1969, s. 424-438).

\section{EMPIRICAL FINDINGS AND EVALUATIONS}

ADF unit root test was performed in E-views 7 to examine the stock market index, Dollar/TL, Euro/TL and interest rate series. As shown in Table 1, there are unit roots in the original time series of variables whose average values are taken according to the unit root test results. To solve the unit root problem in the study, natural logarithms were taken (Benninga, 2000: 18-21). To obtain significant results and to solve the unit root problem of the analysis, natural logarithms were taken. By taking natural logarithms of the data-sets, the structure of the data-sets remains same properties and 
they become stationary which means more significant analysis results would be obtained.

Table 1: Results of ADF Unit Root Tests

\begin{tabular}{|l|c|c|c|c|c|c|c|c|}
\hline \multicolumn{4}{|c|}{ Series } & \multicolumn{3}{c|}{ Logarithm of Series } \\
\hline & \multicolumn{2}{|c|}{ Constant } & \multicolumn{2}{|c|}{ Trend-Constant } & \multicolumn{2}{c|}{ Constant } & \multicolumn{2}{c|}{ Trend-Constant } \\
\hline Variable & $\begin{array}{c}\text { Standard } \\
\text { Error }\end{array}$ & Sig. & $\begin{array}{c}\text { Standard } \\
\text { Error }\end{array}$ & Sig. & $\begin{array}{c}\text { Standard } \\
\text { Error }\end{array}$ & $\begin{array}{c}\text { Sig. } \\
\text { Standard } \\
\text { Error }\end{array}$ & Sig. \\
\hline Borsa & -1.746 .841 & 0.4059 & -3.173 .084 & 0.0935 & -5.687 .711 & 0.0000 & -5.722 .467 & 0.0001 \\
\hline Faiz & -1.626 .787 & 0.4666 & -1.146 .084 & 0.9171 & -4.437 .016 & 0.0004 & -4.592 .159 & 0.0015 \\
\hline $\begin{array}{l}\text { Dolar/ } \\
\text { TL }\end{array}$ & -1.232594 & 0.9983 & -0.891053 & 0.9537 & -11.87507 & 0.0000 & -12.05157 & 0.0000 \\
\hline $\begin{array}{l}\text { Euro/ } \\
\text { TL }\end{array}$ & -0.456207 & 0.9847 & -1.568559 & 0.8014 & -14.30639 & 0.0000 & -14.47641 & 0.0000 \\
\hline
\end{tabular}

- $\quad$ The appropriate number of lag length for the VAR model established in the study was determined with the help of 2, AIC, FPE test.

Table 2: Lag Interval Tests

\begin{tabular}{|c|c|c|c|c|c|}
\hline Lag & LR & FPE & AIC & SC & HQ \\
\hline 0 & NA 177.3907 & $2.83 \mathrm{e}-11$ & -12.93549 & -12.85957 & -12.90467 \\
1 & 37.59959 & $1.12 \mathrm{e}-11$ & -13.86189 & $-13.48229 *$ & $-13.70778^{*}$ \\
$\mathbf{2}$ & 25.56764 & $\mathbf{1 . 0 7 e - 1 1 *}$ & $\mathbf{- 1 3 . 9 0 9 7 3 *}$ & -13.22645 & -13.63232 \\
3 & 18.75785 & $1.10 \mathrm{e}-11$ & -13.88386 & -12.89690 & -13.48316 \\
4 & 30.54096 & $1.18 \mathrm{e}-11$ & -13.81602 & -12.52538 & -13.29203 \\
5 & 30.30758 & $1.16 \mathrm{e}-11$ & -13.83478 & -12.24045 & -13.18750 \\
6 & $26.43512^{*}$ & $1.14 \mathrm{e}-11$ & -13.85808 & -11.96007 & -13.08751 \\
7 & 12.57843 & $1.14 \mathrm{e}-11$ & -13.85904 & -11.65735 & -12.96518 \\
8 & & $1.27 \mathrm{e}-11$ & -13.75948 & -11.25411 & -12.74232 \\
\hline
\end{tabular}

As illustrated in Graph 1, the points represent the roots of the variables and are located within the unit circle. 


\section{Graph 1: AR Unit Root Results}

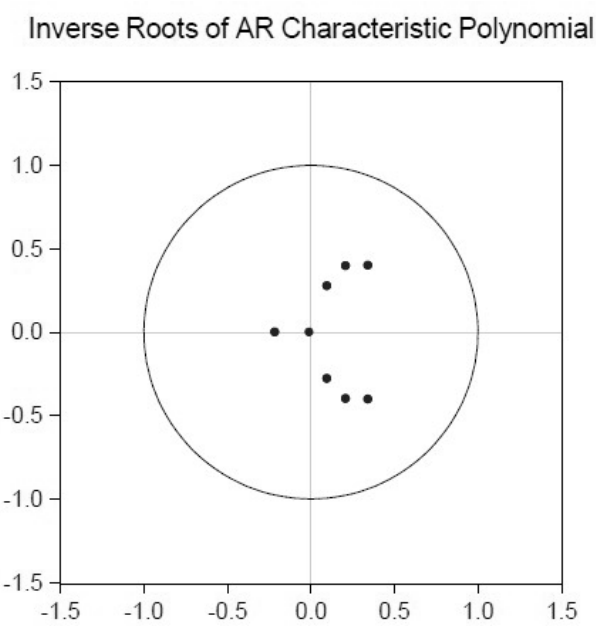

- The LM probability value (prob: 0.0681 ) was found to be greater than 0.05 .

Table 3 illustrates the results of the causality relationship for the stock market index. Accordingly, the $\mathrm{H}_{0}$ hypothesis at the level of 5\% significance was rejected for the Dollar/TL variable. In this context, the causality relationship between Dollar/TL variable to BIST100 variable was determined. These results, with Granger-Huang et al. (2000), Şentürk and Dücan (2014), Delgado et al. (2018), show similarity.

Table 3: Causality Test Result of BIST100 Variable

\begin{tabular}{ccc}
\hline Dependent Variable: & Stock Market Index \\
\hline Not Included & DF & Prob. \\
DOLLAR_TL & 2 & 0.0146 \\
EURO_TL & 2 & 0.4589 \\
Interest & 2 & 0.1901 \\
All & 6 & 0.0445 \\
\hline
\end{tabular}

According to the results of the causality relationship established for Dollar/ TL variable, there was no correct relationship between the variables in the model to the Dollar/TL variable (Table 4). In this context, it can be said 
that there is a one-way causality relationship between the stock market index and the Dollar/TL variable.

Table 4: Causality Test Result of Dollar/TL

\begin{tabular}{ccc}
\hline \multicolumn{3}{c}{ Dependent Variable: Dollar/TL } \\
\hline Not Included & DF & Prob. \\
BIST100 & 2 & 0.2502 \\
Euro/TL & 2 & 0.7566 \\
Interest & 2 & 0.3626 \\
All & 6 & 0.5768 \\
\hline
\end{tabular}

A one-way causality relationship from Dollar/TL to Euro/TL was determined at $10 \%$ significance level according to the causality relationship results for Euro/TL variable (Table 5).

Table 5: Causality Test Result of Euro/TL

\begin{tabular}{ccc}
\hline \multicolumn{3}{c}{ Dependent Variable: Euro/TL } \\
\hline Not Included & DF & Prob. \\
BIST100 & 2 & 0.2689 \\
Dollar/TL & 2 & 0.0688 \\
Interest & 2 & 0.3895 \\
All & 6 & 0.0582 \\
\hline
\end{tabular}

Table 6; the test results for the interest rate variable. According to results, it was determined that the dollar/TL variable at the level of 5\% significance was the cause of the interest rate variable. These results are similar to those of Topaloğlu and Karakozak (2008), Şentürk and Dücan (2014).

Table 6: Causality Test Result of Interest Rate

\begin{tabular}{ccc}
\hline \multicolumn{3}{c}{ Dependent Variable: Interest Rate } \\
\hline Not Included & DF & Prob. \\
Stock Market & 2 & 0.7922 \\
Dolarl/TL & 2 & 0.0038 \\
Euro/TL & 2 & 0.2317 \\
All & 6 & 0.0000 \\
\hline
\end{tabular}


With the effect-response function, the reaction of the BIST100 index variable over time against a unit shock applied to one of the Dollar/ $\mathrm{TL}$, Euro/TL, and interest rate variables were analyzed. In this analysis, confidence intervals required for effect-response functions were obtained using Monte Carlo simulations ( \pm 2 for standard error). As shown in Figure 1, the reaction of BIST100 index variable to a shock in the Dollar/ TL variable was negatively until the third period. It approaches zero equilibrium by taking positive values from the fourth period.

The reaction of the BIST100 index variable to a shock in the Euro/TL variable was positive until the third period. Although it showed a decline of -0.0005 in the fourth period, it was found to be approaching its equilibrium value from this period. The reaction of the stock market index against the shock of a standard error in the interest rate variable is negative until the fourth period, while positive values from this period are observed.

Figure 1: The Results of Impulse-Response Functions
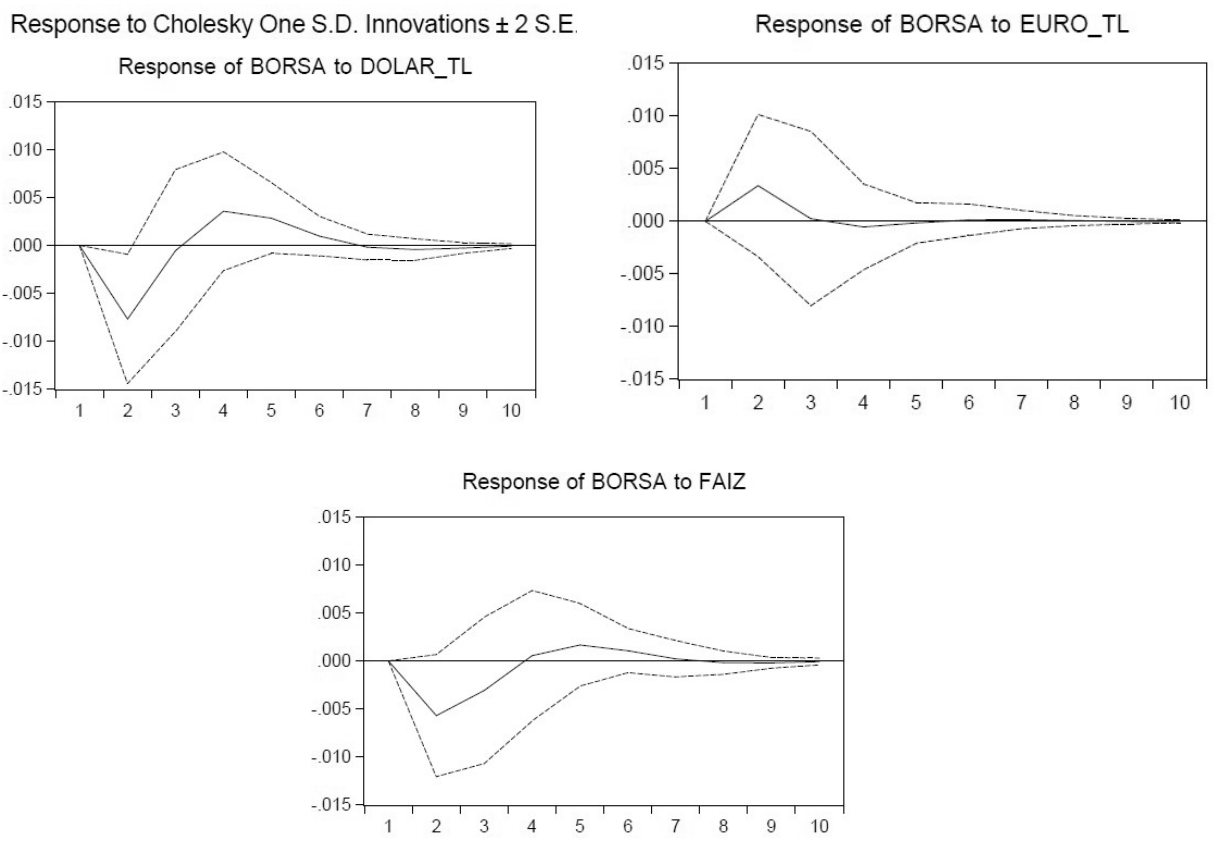


\section{CONCLUSION}

In this study, mutual interaction of Dollar/TL, Euro/TL and interest rates affecting the stock market index for 01/2005 - 03/2019 period were analyzed. The causality relationship between variables in the model with VAR method was evaluated at $5 \%$, and $10 \%$ significance levels. The 10 -year reaction of the stock market index against the sudden shock of exchange rates and interest rate were examined with the effect-reaction function.

There are many studies in both national and international literature that examine the impact of financial and/or macroeconomic factors on stock market indices. Studies examining the causality relationship between exchange rates and the stock market index show that there is not a consensus. As stated in the introduction and literature parts of the study, while some studies show that there is a mutual and meaningful relationship between two variables, some studies have found that there is a one-way relationship. The relationship between the interest rate and the stock market index studies examined shows that there is a significant relationship between the two variables. According to causality analysis results in the study, it was determined that there is a one-way causality relationship from Dollar/TL to BIST100 index variable. This result, Granger-Huang et al.(2000), Şentürk and Dücan (2014), Delgado et al. (2018), shows similarities with his work. The study also found that there is a one-way causality relationship from Dollar/TL to Euro/TL and from Dollar/TL to interest rate variable.

With the effect-response function, the reaction of the BIST100 index variable over time against a unit shock applied to one of the Dollar/TL, Euro/TL and interest rate variables were analyzed. While the stock market variable reacted negatively to a standard error shock in the Dollar/TL index until the third period, it was observed that it received positive values from this period. It was determined that the reaction of the BIST100 index variable to a shock in the Euro/TL variable was positive until the third period, although it showed a decline of -0.0005 in the fourth period, it approached the balance value after from this period. The reaction of the BIST100 index against the shock of a standard error in the interest rate variable was negative until the fourth period, while positive values were taken from this period. 
According to the results obtained from the study, the BIST100 index was found to be sensitive to the Dollar/TL variable. The constraints of research provide opportunities for future studies. It is thought that it would be useful to extend the analysis period to include different variables in the analysis, and to compare Turkey with countries with similar levels of development.

\section{REFERENCES}

[1]Aggarwal, R. (1981). Exchange rates and stock prices: a study of U.S. capital market under floating exchange rates. Akron Business and Economic Review, 12, 7-12.

[2]Akbaş, Y. E. (2013). The Analysis of Relationship between the Rate of Stock Return and Interest Rate with Nonlinear Methods: The Case of Turkey, Business and Economics Research Journal, 4(3), 21-40.

[3]Benninga, S. (2000). Financial Modeling. The MIT Press Cambridge, Massachusetts London, England, Second Edition.

[4]Central Bank Of The Republic Of Turkey (TCMB) Monetary Policy Report. July 2002, s.1-69

[5]Çakmak, E., Aksu, H. ve Başar, S. (2002). Evaluation of Fisher Hypothesis in Turkey: 1989-2001. Atatürk University Journal of Economics and Administrative Sciences, 16(3-4), 31-40. Access address: http://dergipark.gov.tr/atauniiibd.

[6]Delgado, N. A. B., Delgado B. E ve Saucedo, E. (2018). The relationship between oil prices, the stock market and the exchange rate: evidence from Mexico, North American Journal of Economics and Finance, 45, 266-275. [7]Ghazali, M. F., Ismail, W., Yasoa, M.R. \& Lajuni N. (2008). Bivariate causality between exchange rates and stock prices in Malaysia. The International Journal of Business and Finance Research, 2(1), 53-59.

[8]Granger, C. W. J. (1969). Investigating causal relations by econometric models and cross-spectral methods. Econometrica, 37(3), 424-438. doi: 10.2307/1912791.

[9]Granger, C. W. J., Huang, B. N., Yang, C. W. (2000). A bivariate causality between stock prices and exchange rates: evidence from recent asian flu. The Quarterly Review of Economics and Finance, 40, 337-354. 
[10]Gujarati, D.N., Porter, D.C. (2014). Basic Econometrics, (Translation: Ü. Şenesen ve G. G. Şenesen), Literature Publications, Translation From The Fifth Edition.

[11]Hendry, D., Juselius, K. (2000). Explaning cointegration analysis: Part II. The Energy Journal, 22(1), 1-34. doi: 10.2307/41322908.

[12]Nieh, C., Lee, C., (2001). Dynamic relationship between stock prices and exchange rates for G-7 countries. The Quarterly Review of Economics and Finance, 41(4), 477-490.

[13]Sims, C. A., (1980). Macroeconomics and reality. Econometrica, 48(1), 1-48. doi: 10.2307/1912017

[14]Soenen, L.A., Hennigar, E.S. (1988). An analysis of exchange rates and stock prices: the US experience between 1980 and 1986. Akron Business and Economic Review, 19(4), 71-76.

[15]Şentürk, M., Dücan, E. (2014). Relationship between exchange rateinterest rate and exchange rate return in Turkey, Business and Economics Research Journal, 5(3), 67-80

[16] Tabak, B. M. (2006). The dynamic relationship between stock prices and exchange rates: evidence for Brazil. International Journal of Theoritical and Applied Finance, 9(8), 1377-1139.

[17]Topaloğlu, E. E., Karakozak, Ö. (2018). Macroeconomic Factors and Stock Returns: Panel Data Analysis on BIST Banks Index Firms, Journal of accounting and Finance,78, 199-215. 